\title{
Knowledge Atlas on the Relationship between Urban Street Space and Residents' Health-A Bibliometric Analysis Based on VOSviewer and CiteSpace
}

\author{
Lingchao Meng ${ }^{1,2, *}$, Kuo-Hsun Wen ${ }^{3, *}$, Richard Brewin ${ }^{4}$ and Qiong $\mathrm{Wu}^{5}$ \\ 1 School of Fine Arts, Northwest Minzu University, No 1 Northwest New Village, Chengguan Area, \\ Lanzhou 730030, China \\ 2 Faculty of Humanities and Arts, Macau University of Science and Technology, Avenida Wai Long, Taipa, \\ Macau 999078, China \\ 3 School of Arts, Macao polytechnic Institute, Rua Luis Gonzaga Gomes, Macau 999078, China \\ 4 Beijing Normal University, Zhuhai, No 18 Jinfeng Road, Tangjiawan Area, Zhuhai 519000, China \\ 5 Faculty of Business, City University of Macau, Avenida Padre Tomás Pereira Taipa, Macau 999078, China \\ * Correspondence: lcmeng87@gmail.com (L.M.); khwen@ipm.edu.mo (K.-H.W.); \\ Tel.: +86-0931-2938137 (L.M.); +853-85996771 (K.-H.W.)
}

Received: 25 January 2020; Accepted: 11 March 2020; Published: 18 March 2020

\begin{abstract}
In order to draw and analyze the current status of the research on the relationship between international urban street space (public space, public open space) and residents' health, we explore the hotspots and frontiers of this research field and the overall evolution path from 1999 to 2019. This study uses 4552 related research articles included in the core database of Web of Science as the basis for data analysis, and uses the advantages of VOSviewer and CiteSpace's bibliometric visualization software to study countries, institutions, literature keywords, and literature co-citation networks, combined with the Alluvial Generator analysis of landmark literature. In this research area, the research content is constantly enriching, including urban street networks, health systems, green spaces, road traffic, thermal comfort, and vulnerable people. The research methods are also constantly enriching. By analyzing and sorting out the current research status, research hotspots and possible future trends in this field of research, the paper hopes to provide more reference for research implementation.
\end{abstract}

Keywords: urban street space; residents' health; knowledge map; quantitative analysis

\section{Introduction}

In the middle and late 18th century to the middle and late 19th century, the industrial revolution brought about social changes and prompted changes in urban space. Taking the United States as an example, the urbanization rate increased from $20 \%$ to $40 \%$ from 1860 to 1900 [1]. Edwin Chadwick (1800-1890) once pointed out that the problem of urban space conditions, such as "crowded living space, swollen living space, open sink and toilets, unclean domestic water" and other diseases lead to diseases [2]. The improvement of urban life and production efficiency, and the subsequent urban problems have also emerged one after another. The surge in urban population, the increase in urban pollution (waste, sewage, etc.), and the spread of infectious diseases in cities have brought pressure on urban public health. In the late 1960s, smallpox, cholera and other epidemic outbreaks brought threats to the health of urban residents. However, the important public space components of the city, such as streets, green spaces, and squares, could not effectively resolve these contradictions, but became nourishing. One of the places where germs and epidemic diseases spread, has caused the public to be strongly dissatisfied with the public health prevention and quarantine mechanism, and issued a call for 
health reform [3]. Based on progressive public health experts represented by George Wehring, it argues that the dirty environment of public places is not only a breeding ground for various diseases, but also a symbol of social disorder, despair, and crime [4]. According to Lewis Murnford, he stated that

Every city in the western world, more or less, has the characteristics of 'Coketown'. The main creativity of the 19th century produced an extremely deteriorating urban environment that has never been achieved before; because even the ruling class settlements were polluted and very crowded. Indeed, the richest and most 'advanced' metropolises don't even have enough sunshine and fresh air to build basic things that are indispensable to life, but backward villages still have these things. [5]

Since the 1940s, the spectrum of human diseases has begun to change. Although the problem of infectious diseases still exists, "chronic diseases and non-communicable diseases" have become the main diseases that threaten the health of human residents. New urban problems such as "Urban Sprawl" and "Suburbanization" have begun to appear, causing a series of economic and social problems, and new spatial diseases caused by these urban problems have also begun to appear [6]. In 1946, the World Health Organization defined the health of residents as "Not just free of disease or weakness, but a state of complete physical, mental, and social resident health" [7]. A study by World Habitat suggests that the well-functioning of about $50 \%$ of the city's surface area is dedicated to public space. Unfortunately, tfew cities in the world achieve this goal. The lack of high-quality public space reduces the quality of life in cities, increases crime, social tension, residents' health, and traffic congestion. Public space provides leverage for optimizing urban performance-building safer, more cohesive communities, reducing spatial inequality, building a local economy, and bringing nature back to cities [8].

City managers and city researchers began to study the relationship with residents' health and the factors that affect residents' access to residents' health from various types of urban spaces and different professional perspectives. Jane Jacobs proposed the "street eye" (safety, public life, City fun). The street, especially the sidewalk, is the most important place for public activities in the city and the most vital "organ" in the city. In addition to the traffic function, urban streets have three other functions: safety, access and assimilation of children [9]. American sociologist Erving Goffman's "Behavior in Public Places", from the perspective of psychology, distinguishes the different ways and behaviors of people gathering in public places, and studies the interaction between people, and between people and space [10]. According to William H. Whyte, a basic point of good urban public space is supply generates demand. Good, new public spaces will generate new users. Good, new public spaces are driving people to produce new lifestyles-open air lunches-to create a new way to work and where to stop. William $\mathrm{H}$. Whyte analyzes the public life elements of street space from the perspective of bench space, sunlight, wind, trees, water, and food in street space; these elements of public life are also the basic elements for residents to obtain health in the street space [11]. In 1982, Morphologie: City Metaphors, Wengers argued that urban structure is like a contrast between mechanical structure and human body structure. "Human health" and "urban space" are connected in an interesting way. Wengers likens the "urban infrastructure system" by "skeletal system," "digestive system," "circulatory system" and "nervous system." As urban expansion and functions continue to increase, urban space has established a closer relationship with the health of human residents [12]. In the urban design and architectural design, "resident health" is gradually incorporated into the design process, and the scope of design thinking has also expanded from "prevention of pollution" to "spatial treatment" and even "spatial prevention."

In 2003, British scholar Hugh Barton and others published Shaping Blocks: Residents' Health, Sustainability, and Vitality, which introduced a series of design strategies for preventing diseases and promoting residents' health, starting from the scale of block design [13]. New York issued the Active Design Guidelines: Promoting Physical Activity and Health in Design in 2010, to promote public physical activity and residents' health through proactive urban planning and design guidelines. In the same year, the government proposed Guidelines for the Design of Public Resident Health Spaces in New York City. 
This guideline proposes a design strategy for the physical space level of the city in response to obesity and related diseases, the most serious residents' health crisis in the United States [14]. Global Residents' Health 2035 points out that the improvement of the built environment can promote the improvement of living environment, roads and safety, physical activity and ambient air, so as to achieve the promotion of residents" health [15]. As an important part of urban public space, street space spreads like "human blood vessels" in all corners of the city and is the main place where residents' daily activities occur [16]. Along with the WHO report, Non-Communicable Diseases (NCD) cause 41 million deaths every year; that is, 71 percent of the global death toll. The impact on low- and middle-income countries is more severe, as these countries account for more than three-quarters of the world's NCD deaths (32 million people) [17].

Due to historical background, geographical location, human factors, living habits and other factors, the street spaces in different cities are different from each other and their own particularity, thus causing different health-related problems. These are the criticisms brought about by the rapid acceleration of urbanization caused by technological innovation. Urban residents have also put forward new requirements for the function of urban street space. In addition to preventing and controlling infectious epidemics, attention must also be paid to the improvement of residents' chronic diseases, including physical, psychological and social residents' health, and to promote social equity and social harmony, etc. However, researchers face similar issues:

1. The continuous emergence of new technologies and methods provides new possibilities for research;

2. How to consider other disciplines so that the research content can be an effective system for solving problems.

\section{Data Sources and Methods}

\subsection{Data Sources}

In order to ensure the scientific and integrity of the data source, this research literature is derived from the core collection of the Web of Science (WOS) database. Retrieved by Topic = "street public open space" or "street space" or "street public space" and "Health", the source of the database is SCI-EXPANDED, SSCI, A \& HCI, CPCI-S, CPCI-SSH, the time span is 1999-2019, and the retrieval time is September 16, 2019. The document type was journal articles, and a total of 552 articles were retrieved.

\subsection{Research Method}

With the rapid development of data mining, information analysis and graphics rendering technology, it becomes possible by using software programs to analyze large volumes of literature data and implementing data expression through the outcome of data visualization. CiteSpace is a visual analysis software based on text mining. It uses the hot word analysis function to draw a knowledge map of the scientific field to visually display the information panorama of each discipline. The knowledge map can reflect the research hotspots and development trends at a certain stage [18,19]. VOSviewer is a software tool developed by Van Eck and Waltman of Leiden University in the Netherlands to build and visualize econometric networks. It can build networks for journals, researchers, keywords, and publications based on co-citation, coupling and co-authoring relationships, and visualize the results [20].

This research is based on the literature data of the research area of street space and residents' health. It uses two kinds of bibliometric analysis tools, VOSviewer and CiteSpace, to perform quantitative analysis on the relevant literature to form the corresponding knowledge map, identify the knowledge base of the research area, and provide the latest progress of related research, frontier hotspots, evolution paths, and future development trends of street space and residents' health research which are intended to provide references and basis for related domestic research. 


\section{Analysis of Developments in Research Fields}

\subsection{Literature Development Trends}

As can be seen from Figure 1, the number of literatures in the study area in the Web of Science database was on the rise, year by year between 1999 and 2019 (Note: the main types of literatures are articles, proceeding papers and book chapters). There was a fluctuation in 2000, 2001 and 2003; and in 2015 , the number of articles published in this field increased significantly. The results show that the overall degree of research and attention in this field is increasing.

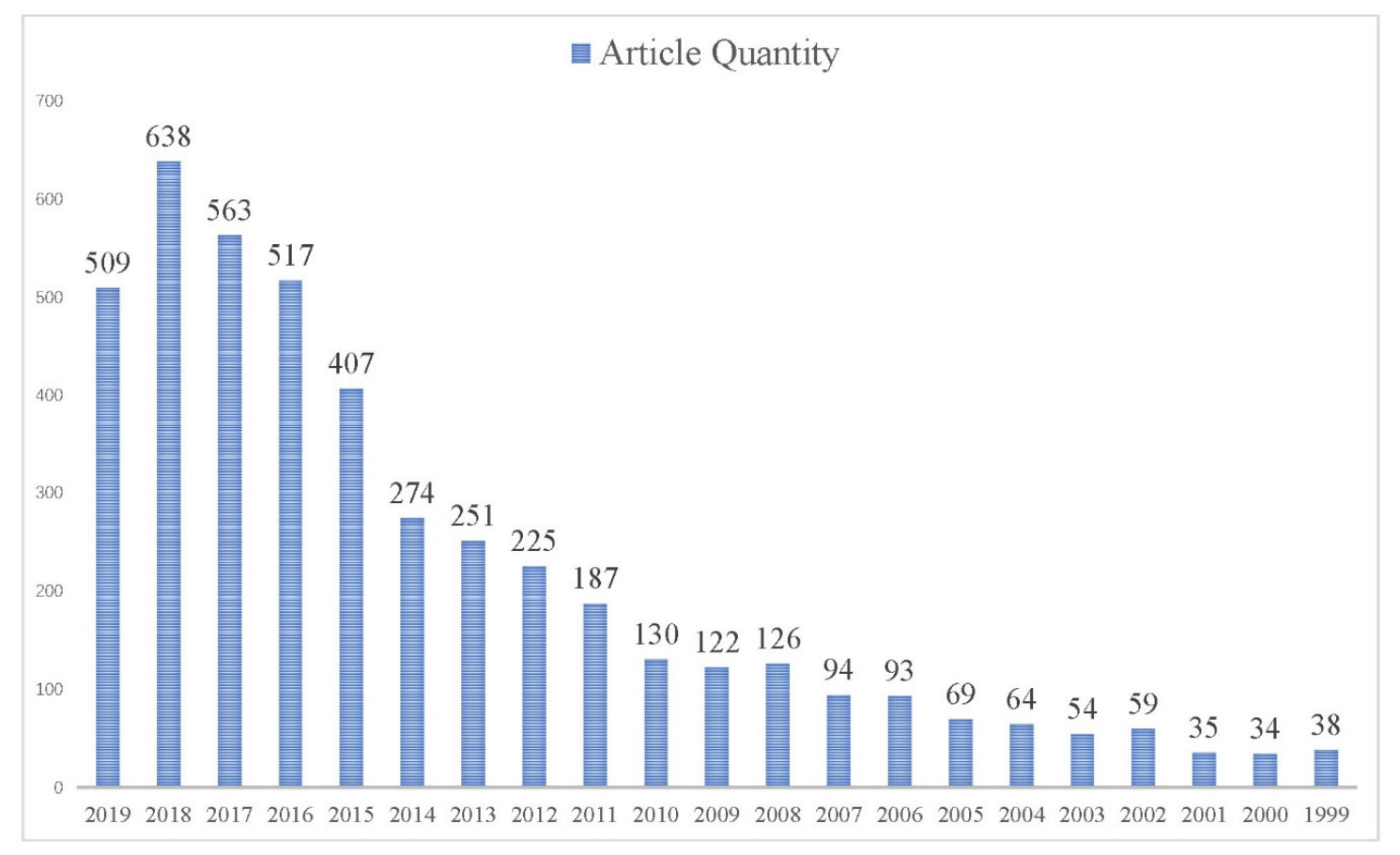

Figure 1. Schematic diagram of document quantity.

\subsection{Country and Research Institute Analysis}

Based on the author's cooperation relationship, VOSviewer is used to visually analyze the cooperation and influence of the country and research institutions. From 1999 to 2019, there are 109 major research countries involved in the research of street space and residents' health. The threshold was set as 5 and 67 countries reached this threshold. It can be seen from Figure 2 that with its absolute cooperative influence, the USA has become the main research country in the research field of the relationship between street space and residents' health. United Kingdom, People's Republic of China and Australia accounted for $12.93 \%, 8.67 \%$, and $6.45 \%$ of the global total. The total link strengths were: 247,227 , and 152 .

From 1999 to 2019, a total of 3039 research institutions were involved in the research field of the relationship between street space and residents' health. The threshold was set to 5 , and a total of 326 research institutions reached this threshold. It can be seen from Figure 3 that the most influential research institution is University College London (UCL). The institution's documents are 66. The main research contents are virtual reality, street-scale, number recognition, remote memory, spatial scale, space syntax, and so on.

The second-ranked institution, University of Melbourne, has 50 documents. Its main research contents include urban climate, thermal infrared remote sensing, network analysis, disruptive innovation, community engagement, climate change adaptation, etc.

The third is University of Hong Kong, whose documents are 47. The main research contents are urban greenspace, compact city, sustainable city, stress reduction, 3-D visual media, thermal comfort, urban morphology, etc. 


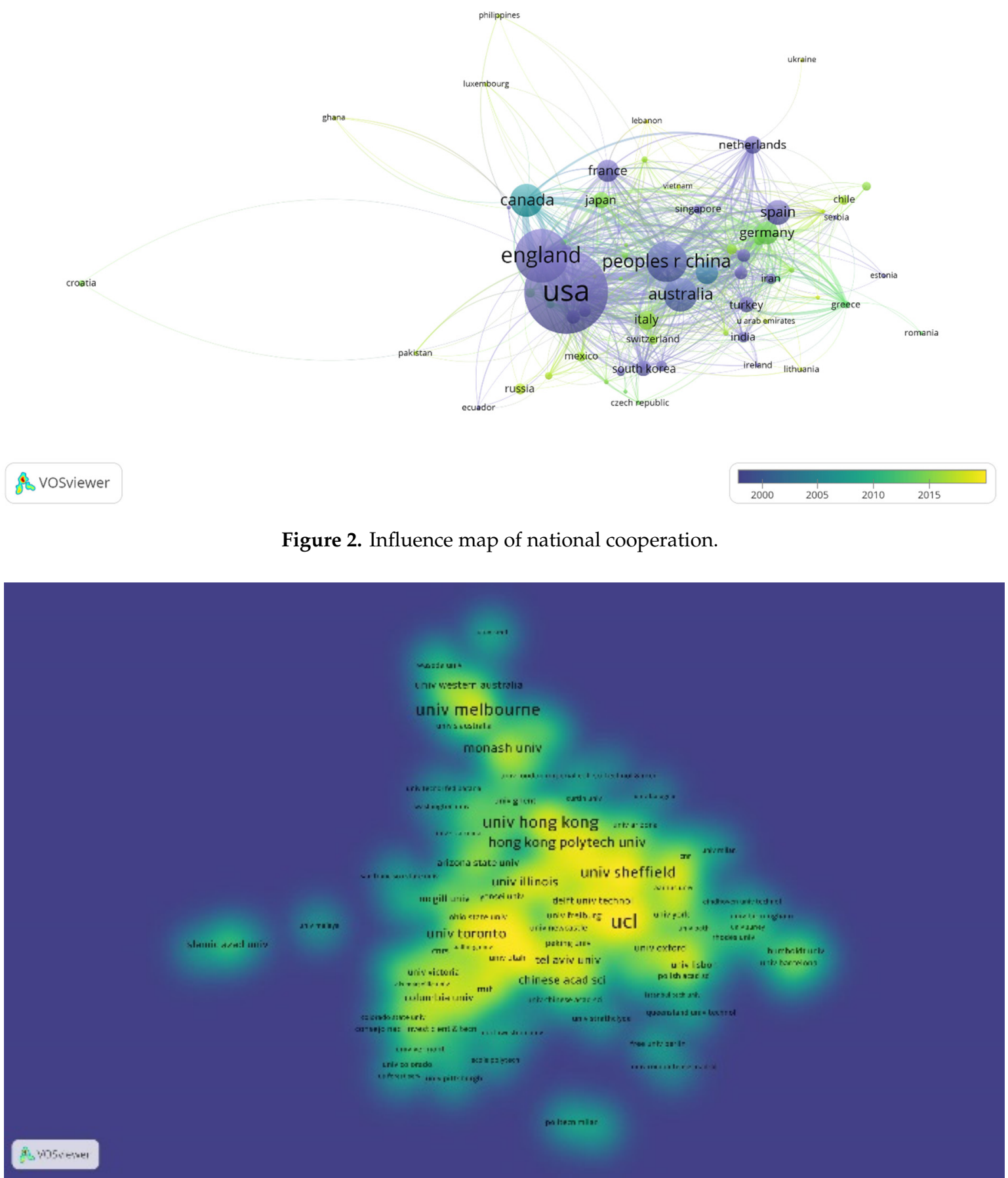

Figure 3. Influence chart of institutional cooperation in research field.

\section{Theme and Domain Co-occurrence Analysis}

Word frequency analysis method refers to the method of extracting keywords or subject words that can express the core content of the document from the document's information and distributing them in high and low order to study the development trend and research hotspots in this field. Compared with the co-citation of literature, co-word analysis is a very intuitive method. Based on the results of the co-word analysis, this article analyzes the topics in the research field of the relationship between street space and residents' health, so as to analyze the hot content, topic distribution, and subject structure of the research field. 


\subsection{Keywords Co-occurrence}

The analysis of the knowledge evolution path in the subject area can help researchers systematically grasp the evolution track of the subject area research, predict the development trend of the research area, and provide researchers with further research objects. In previous studies, some researchers used quantitative calculations based on the occurrence frequency or co-occurrence frequency of vocabulary or phrases that express the research content, based on the strength of the correlation between the topic words to cluster them, and draw a network of subject topics in different periods' atlases to observe the evolution track of subject knowledge [21,22].

Compared with the analysis based on word frequency or co-occurrence word frequency, the analysis of the research evolution path based on emergent words can more easily detect the emerging fields and development trends of scientific research. This research uses CiteSpace for burst detection. Burst detection in CiteSpace is mainly based on the Kleinberg algorithm [23]. By examining the word frequency, those words with a high rate of change in word frequency in a certain period of time are detected from a large number of subject words.

Co-occurrence of keywords is a co-occurrence analysis of keyword fields provided by authors in the Web of Science dataset. The CiteSpace software was used to analyze public space thesis papers with a time slice of 4 from 1999 to 2019, and 10 keywords co-occurrence clustering was detected. As can be seen from Figure 4, the high-frequency keywords ranked among the top 10. They are space, city, public space, street, environment, model, physical activity, politics, build environment, health. It is found from Figure 5 that CiteSpace also analyzed the emergence of keywords. The top 10 emergence strengths are homelessness, flow, women, circular cylinder, infrastructure, violence, dynamics, system, risk, and temperature. Among them, mobility, street art, pedestrian, graffiti, street tree, and infrastructure are emergent words appearing in 2015-2019. Combining the displayed temporal emergent words, the evolutionary path of literature keyword topics, and the co-occurrence clustering of literature keywords (Figure 6), it can be seen that the research on street space and residents' health in the past 20 years can be significantly divided into 3 stages.

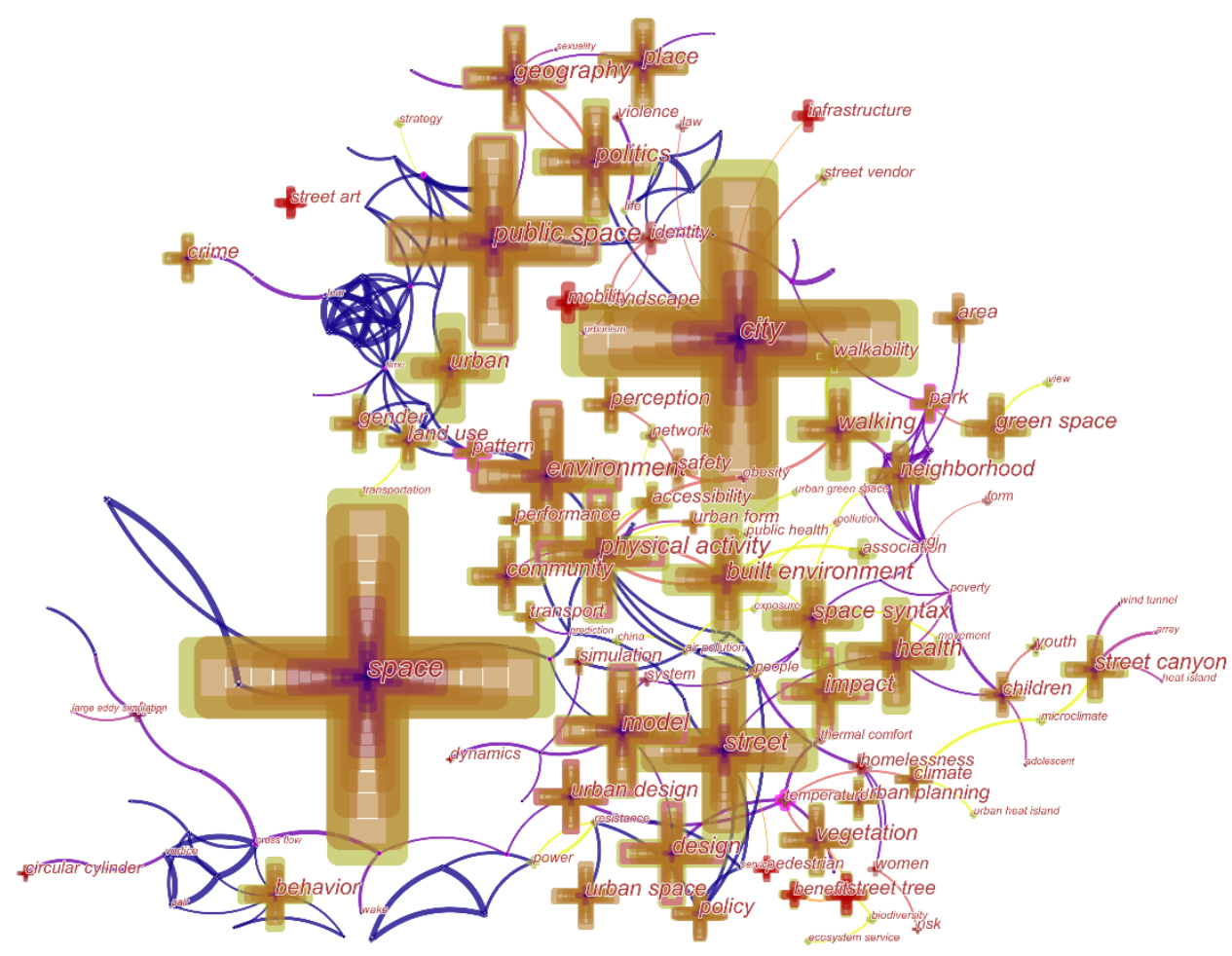

Figure 4. Keywords co-occurrence network. 
Top 25 Subject Categories with the Strongest Citation Bursts

\begin{tabular}{|c|c|c|c|c|c|}
\hline Subject Categories & Year & Strength & Begin & End & $1999-2019$ \\
\hline circular cylinder & 1999 & 10.1698 & 1999 & 2014 & \\
\hline flow & 1999 & 13.146 & 1999 & 2010 & \\
\hline identity & 1999 & 6.4985 & 2000 & 2014 & \\
\hline dynamics & 1999 & 9.2251 & 2001 & 2014 & \\
\hline simulation & 1999 & 6.9767 & 2001 & 2008 & \\
\hline poverty & 1999 & 5.5166 & 2003 & 2010 & \\
\hline violence & 1999 & 9.2282 & 2003 & 2013 & \\
\hline women & 1999 & 10.3594 & 2003 & 2014 & \\
\hline homelessness & 1999 & 13.2364 & 2005 & 2014 & \\
\hline risk & 1999 & 8.8247 & 2007 & 2014 & \\
\hline wind tunnel & 1999 & 5.4699 & 2007 & 2010 & \\
\hline system & 1999 & 9.1391 & 2011 & 2014 & \\
\hline obesity & 1999 & 7.7998 & 2011 & 2014 & \\
\hline network & 1999 & 6.2963 & 2011 & 2014 & \\
\hline youth & 1999 & 7.1252 & 2011 & 2014 & \\
\hline form & 1999 & 6.8219 & 2011 & 2014 & \\
\hline temperature & 1999 & 8.726 & 2011 & 2014 & \\
\hline gis & 1999 & 8.1592 & 2011 & 2014 & \\
\hline law & 1999 & 7.3107 & 2011 & 2014 & \\
\hline mobility & 1999 & 7.3212 & 2015 & 2019 & \\
\hline street art & 1999 & 8.6232 & 2015 & 2019 & \\
\hline pedestrian & 1999 & 7.2878 & 2015 & 2019 & \\
\hline graffiti & 1999 & 6.6213 & 2015 & 2019 & \\
\hline street tree & 1999 & 5.7455 & 2016 & 2019 & \\
\hline infrastructure & 1999 & 9.3052 & 2017 & 2019 & \\
\hline
\end{tabular}

Figure 5. Keyword emergence list ordering by burst strength.

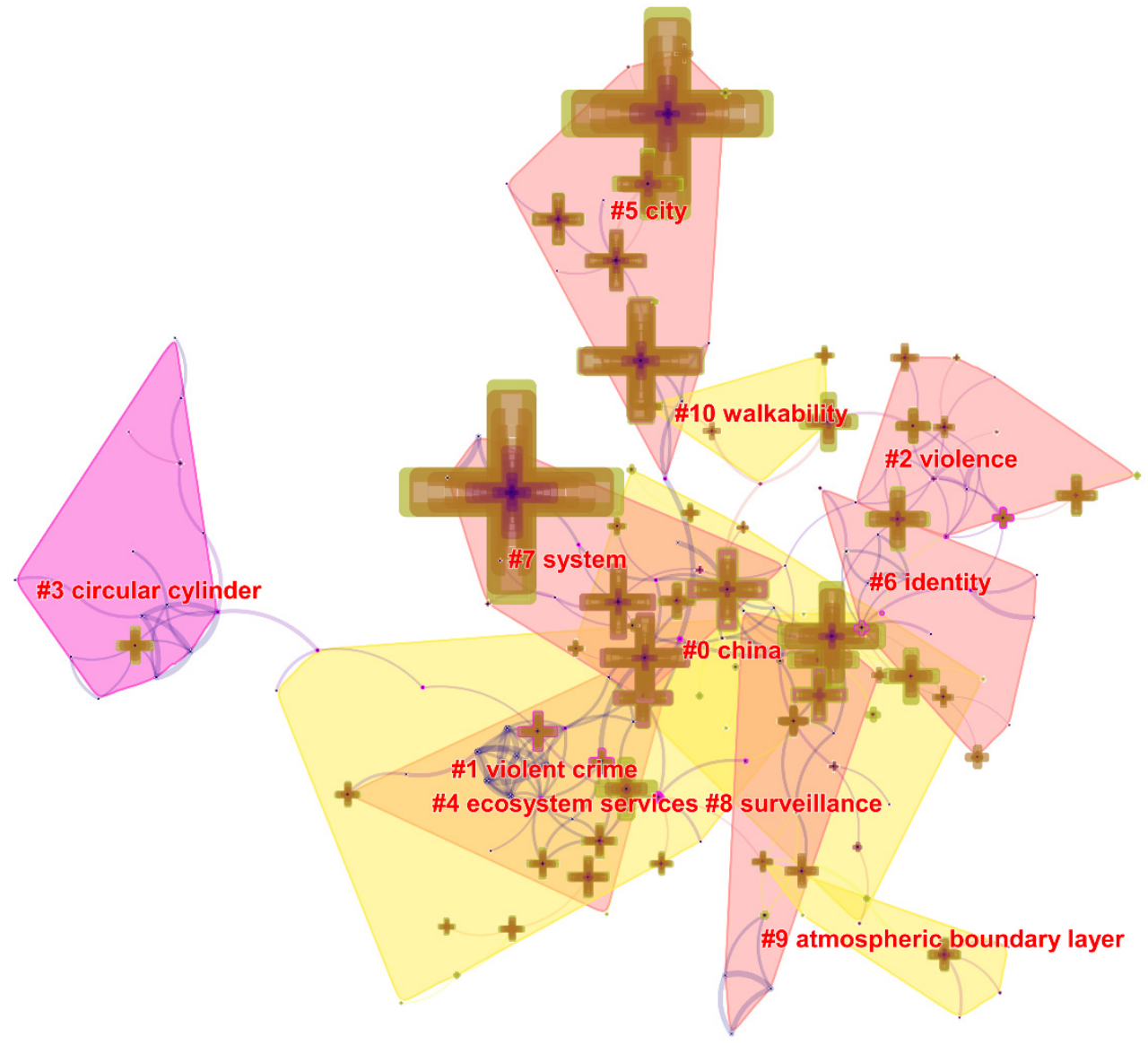

Figure 6. Keywords co-occurrence clustering graph. 
From 1999 to 2003, it can be seen from the keywords co-occurrence map that the research areas of street space and residents' health during this period were space, noise, model, design, system, atmosphere, simulation, dynamics; urban, gender, land use, behavior, urban space; environment, children, etc. As the forefront branch of later research, with the development of subsequent research, it can be seen from the co-occurrence map of keywords from 2007 to 2011 that the street space and the health of residents are public spaces during this period; city, street vendor; physical activity, community; street canyon, vegetation, etc. During 2015-2019, impact, pollution; street tree, benefit; accessibility, network; biodiversity, ecosystem service; space syntax, movement; walk ability, etc.; it can be seen that the research methods and methods of street space and residents' health during this period were more abundant and scientific, and entered a comprehensive, diversified, humane, three-dimensional research stage.

\subsection{Domain Co-occurrence}

The domain co-occurrence network diagram is obtained according to the analysis by CiteSpace software (Figure 7). The following information can be obtained from the analysis of the data: the total number of network nodes is $93(\mathrm{~N}=93)$, the nodes are connected by 113 links $(\mathrm{E}=113)$, and the density of the research field network is 0.0264 (Density $=0.0264$ ). As a result, it indicates that there are fewer cross-references between literatures. The top ten high-frequency domain words are Environmental Sciences and Ecology, Geography, Urban Studies, Environmental Studies, Engineering, Public Administration, Regional and Urban Planning, Engineering, Civil, Transportation, Architecture, Environmental Sciences. According to Figure 8, the top 10 mutation domain words detected by CiteSpace software are: physics, fluids and plasmas, humanities, multidisciplinary, physics, arts and humanities, other topics, and mechanics. Among them, education and educational research is a field emerging discipline from 2015 to 2019 (Figure 8).

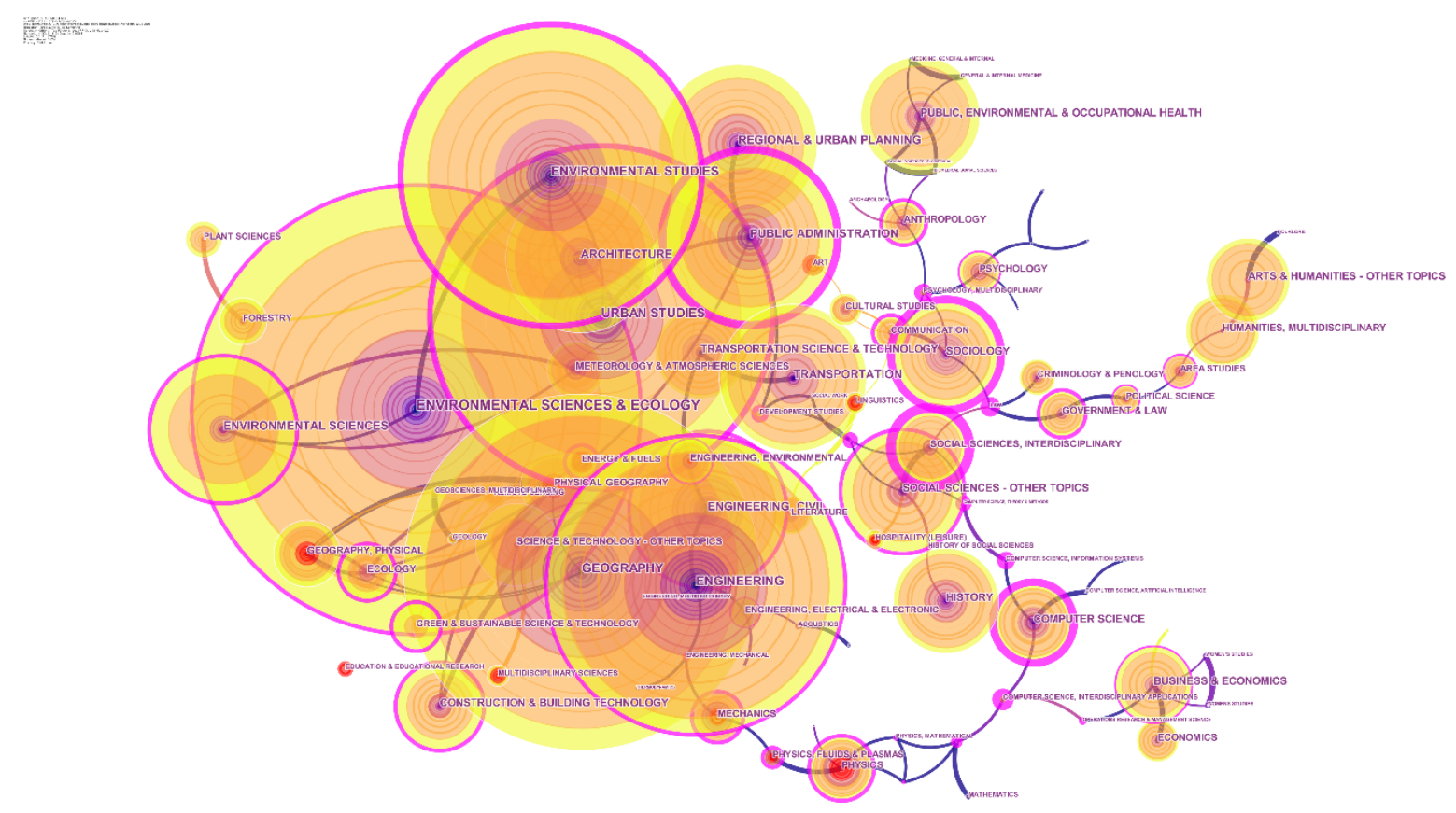

Figure 7. Co-occurrence network. 
Top 12 Subject Categories with the Strongest Citation Bursts

\begin{tabular}{|c|c|c|c|c|c|}
\hline Subject Categories & Year & Strength & Begin & End & $1999-2019$ \\
\hline MATHEMATICS & 1999 & 8.0613 & 1999 & 2014 & . \\
\hline MECHANICS & 1999 & 11.7596 & 1999 & 2012 & \\
\hline PHYSICS, FLUIDS \& PLASMAS & 1999 & 20.1209 & 1999 & 2011 & \\
\hline PHYSICS & 1999 & 15.5754 & 1999 & 2011 & \\
\hline PHYSICS, MATHEMATICAL & 1999 & 7.2727 & 1999 & 2010 & \\
\hline ENGINEERING, MECHANICAL & 1999 & 7.6941 & 1999 & 2006 & \\
\hline ACOUSTICS & 1999 & 10.2284 & 2001 & 2013 & \\
\hline COMPUTER SCIENCE, INTERDISCIPLINARY APPLICATIONS & 1999 & 10.0222 & 2005 & 2014 & \\
\hline EDUCATION \& EDUCATIONAL RESEARCH & 1999 & 7.6921 & 2015 & 2019 & \\
\hline HUMANITIES, MULTIDISCIPLINARY & 1999 & 17.4044 & 2015 & 2017 & \\
\hline ARTS \& HUMANITIES - OTHER TOPICS & 1999 & 12.4307 & 2015 & 2017 & \\
\hline ART & 1999 & 9.9069 & 2016 & 2019 & \\
\hline
\end{tabular}

Figure 8. Sorting of emergent lists in the literature area by burst intensity.

\section{Co-cited}

Co-citation of a document refers to the fact that two documents (or multiple articles) appear in the third bibliographic reference list, then the two documents form a co-citation relationship, which can be explored through literature co-citation research which has become the development and evolution of a discipline. Figure 9 demonstrates the analysis of co-citation to 4552 related research papers in the WOS from 1999 to 2019, and the results in Table 1 were obtained according to the frequency of citations. From the analysis of the data, the following information can be obtained: the total number of network nodes is $436(\mathrm{~N}=436)$, there are 688 connections $(\mathrm{E}=113)$ between the nodes, and the density of the total cited literature network is 0.0073 (Density $=0.0073$ ), indicating that there are fewer cross-references among literatures. In the figure, the size of the circle is affected by the "cited frequency." At the same time, the distance between circles can be seen to realize which literatures are closely related (the strong connection indicates that these literatures will often appear together in later research publications). Among them, the most cited literature is Tzu-Ping Lin's Shading Effect on Long-Term Outdoor Thermal Comfort; Andreas Matzarakis's Modelling Radiation Fluxes in Simple and Complex Environments: Basics of the RayMan Model; third place is Limor Shashua-Bar's (2011), The Influence of Trees and Grass on Outdoor Thermal Comfort in a Hot-Arid Environment; fourth place is Jennifer R. Wolcha's (2010), Urban Green Space, Public Health, and Environmental Justice: The Challenge of Making Cities 'Just Green Enough'; fifth place is Diana E. Bowler's Urban Greening to Cool Towns and Cities: A Systematic Review of the Empirical Evidence. In the citation list of the top 10 documents in Table 1, there are 4 documents cited more than 30 times; 6 documents cited more than 20 times.

Table 1. Literature co-citation list.

\begin{tabular}{ccc}
\hline Count & Cited References & Year \\
\hline 39 & LIN TP, BUILD ENVIRON, V45, P213 & 2010 \\
39 & MATZARAKIS A, INT J BIOMETEOROL, V54, P131 & 2010 \\
33 & SHASHUA-BARL, INT J CLMATOL, V31, P1498 & 2011 \\
32 & WOLCH JR, LANDSCAPE URBAN PLAN, V125, P234 & 2014 \\
29 & BOWLER DE, LANDSCAPE URBAN PLAN, V97, P147, & 2010 \\
29 & GEHLJ,2011, LIFE BUILDINGS USING, VO, PO & 2011 \\
26 & LI XJ, URBAN FOR URBAN GREE, V14, P675 & 2015 \\
26 & LIN TP, BUILD ENVIRON, V44, P2017 & 2009 \\
23 & LEE H, 2016, LANDSCAPE URBAN PLAN, V148, P37 & 2016 \\
23 & MULLANEY J, 2015. LANDSCAPE URBAN PLAN, & 2015 \\
\hline
\end{tabular}




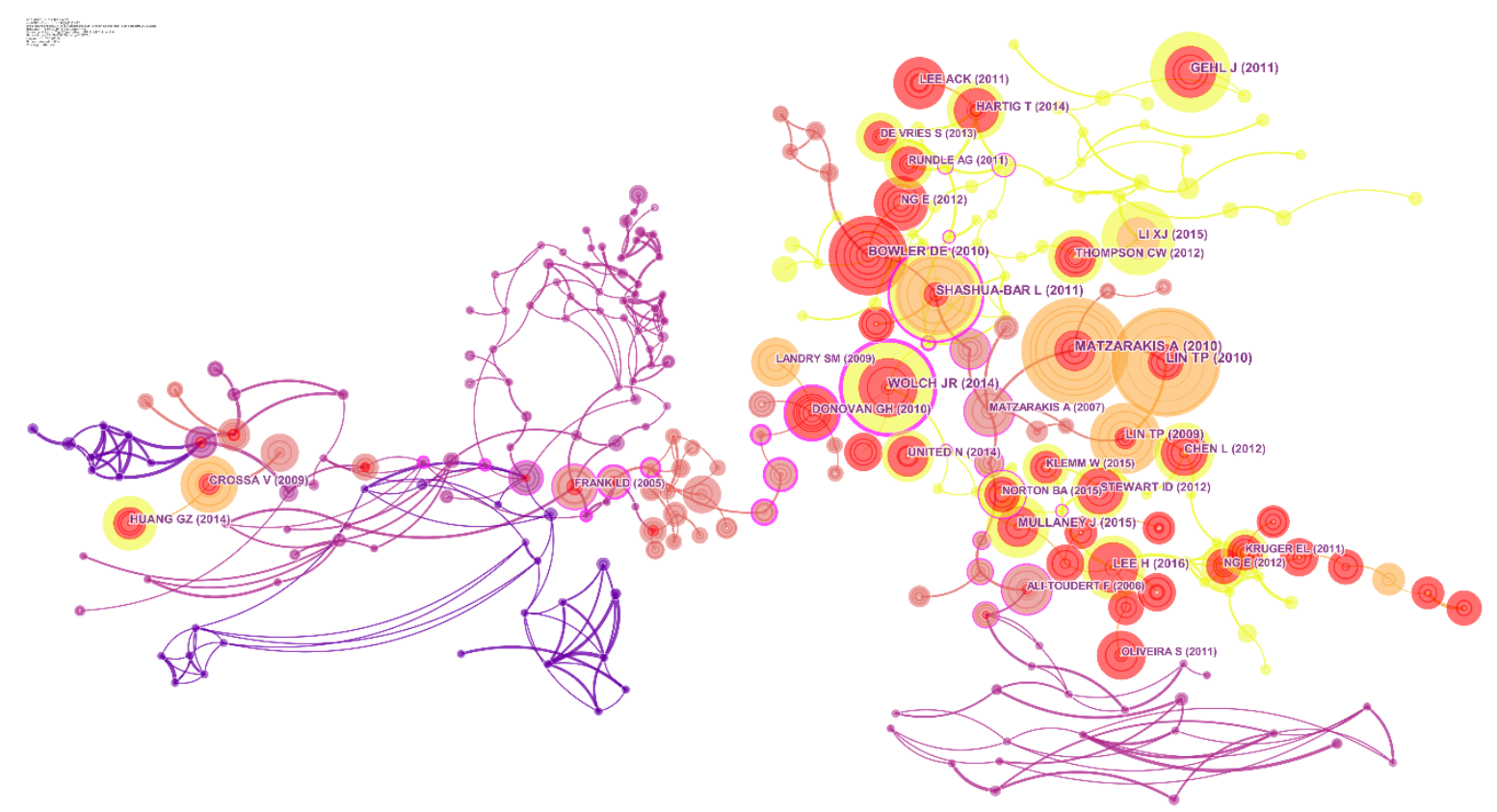

Figure 9. Document co-citation cluster diagram.

\section{Knowledge Topic Identification and Landmark Literature Analysis}

\subsection{Knowledge Topic Recognition}

The research field can be conceptualized as a time map from the research front to the knowledge base [24]. The cited literature in the literature data set constitutes the knowledge base of the research field, and the corresponding cited literature forms the research front. Therefore, subject clustering of citing documents based on the co-citation relationship of the highly cited documents that constitute the knowledge base can, to a certain extent, identify the frontier knowledge base of the research field. On the one hand, it reveals important knowledge turning points in the research frontier evolution. On the other hand, it also lays the foundation for clarifying the relationship between research fronts. This study uses CiteSpace to draw a knowledge map of the research area based on the literature co-citation network to identify research topics in the field of street space and residents' health. The specific parameter configuration is the time cutting is set to 4 years, and the source of the topic words is title, abstract, author keywords, topic type selects noun phrases, node type selects cited literature, threshold selects TOP50 as the threshold, and pruning scheme selects the minimum spanning tree algorithm to trim the time zone segmented network. The map includes 436 nodes and 688 edges. The module's $Q$ value is 0.9122 and the average contour $S$ value is 0.5521 . These two indicators are an important basis for evaluating the effect of graph drawing. For Figure 10, such $Q$ and $S$ values indicate that the clustering structure is significant and the clustering is reasonable.

As can be seen from Figure 10, there are 12 clusters in the topic clustering map of the research area of street space and residents' health from 1999 to 2019. These clusters reflect the hot topics in the field in the past 20 years. The number of documents in each topic cluster show that there are large differences in scale, with a maximum of 33 articles and a minimum of 11 articles, and the time span covered by the cluster is also different (Figure 11), such as 0 cluster destination, which lasted from 2006 to 2018. Some research topics have appeared intensively since 2010 and have continued to the recent (2018) studies, such as 5 cluster street, 8 cluster ecosystem services, and 10 cluster pedestrian-level thermal comfort. 


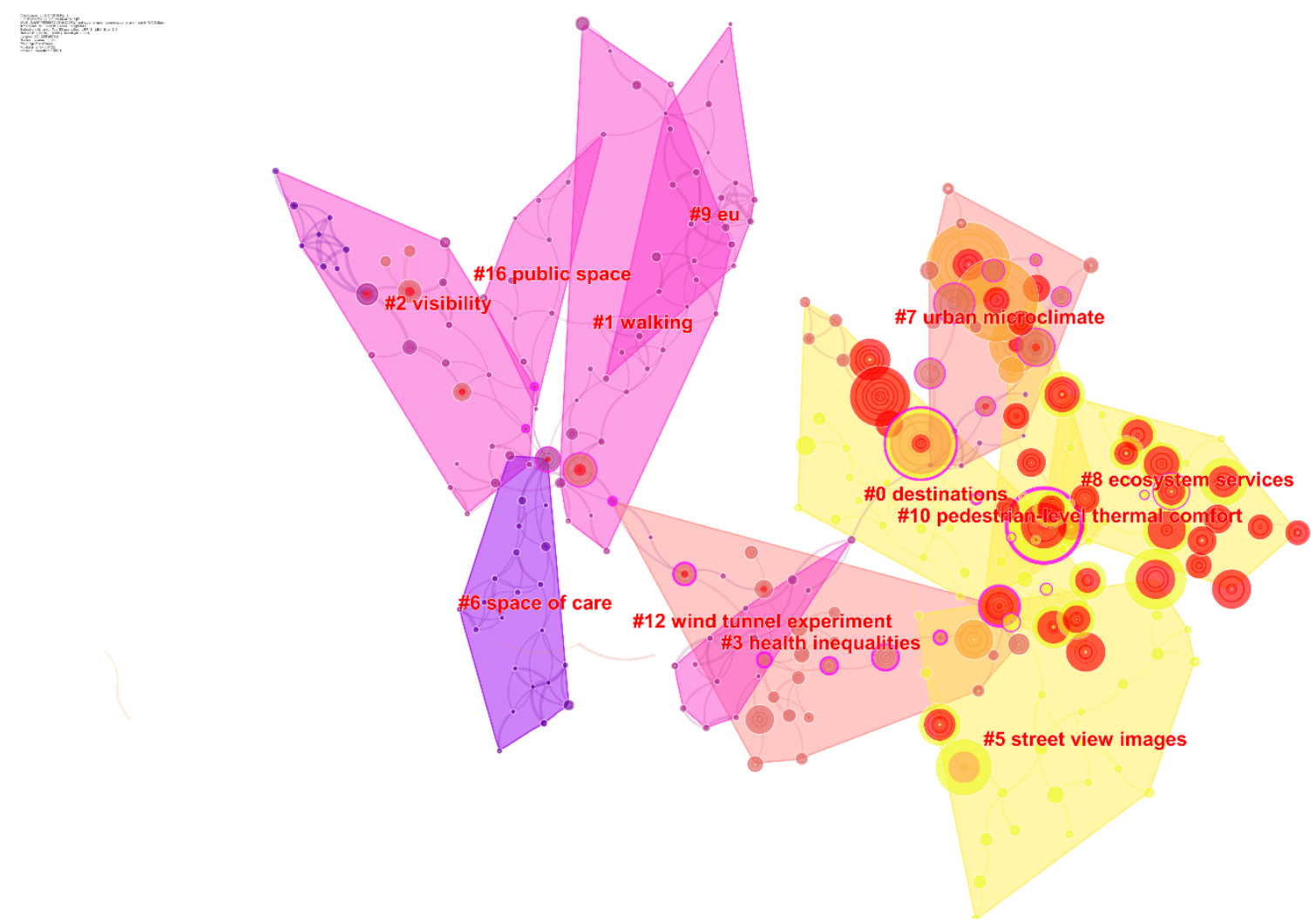

Figure 10. Cluster of research topics.

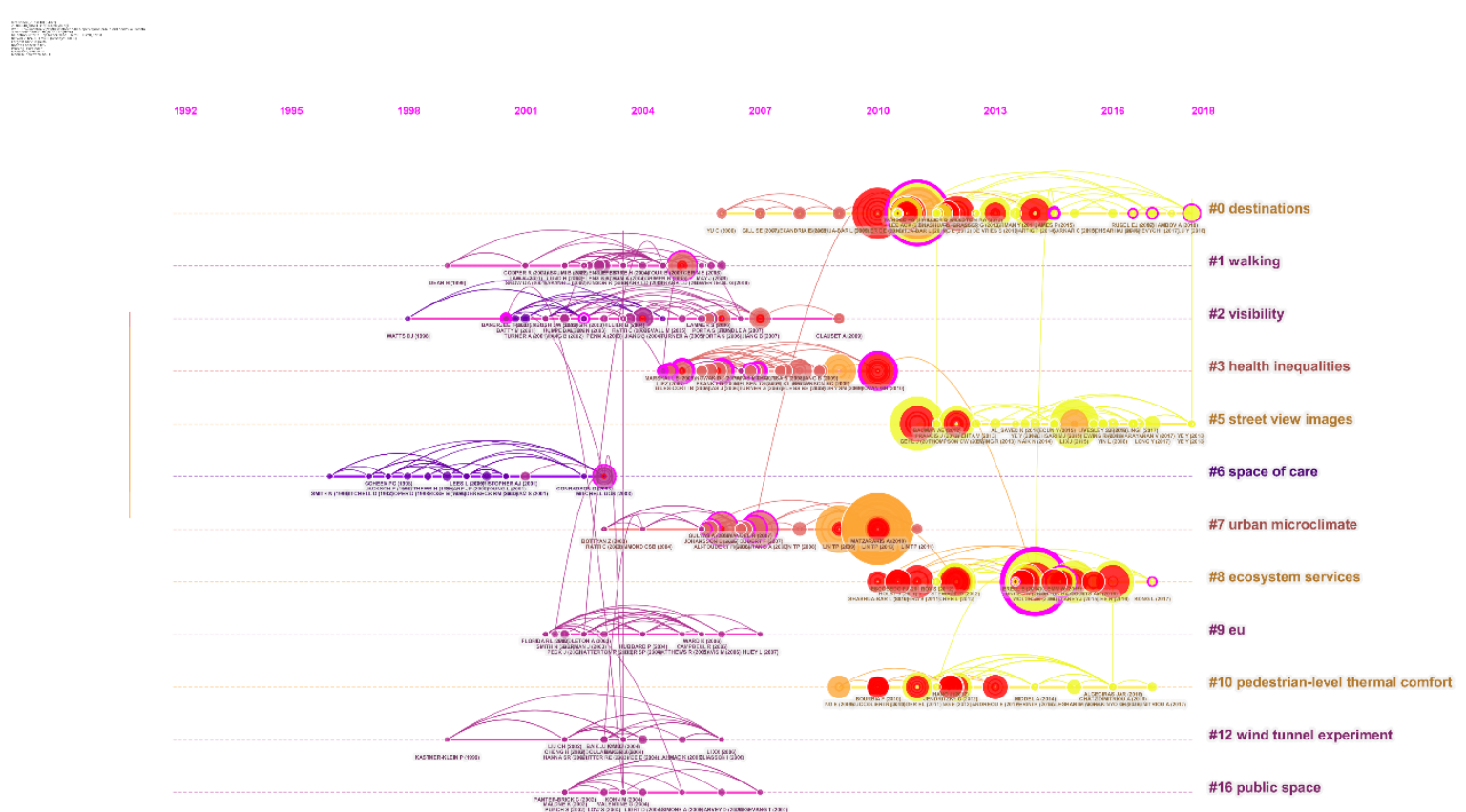

Figure 11. Research topic timeline view.

Combined with the graphical conditions of Figures 10-12, the clustering literature of continuous research in recent years is analyzed, and the results are as follows: 


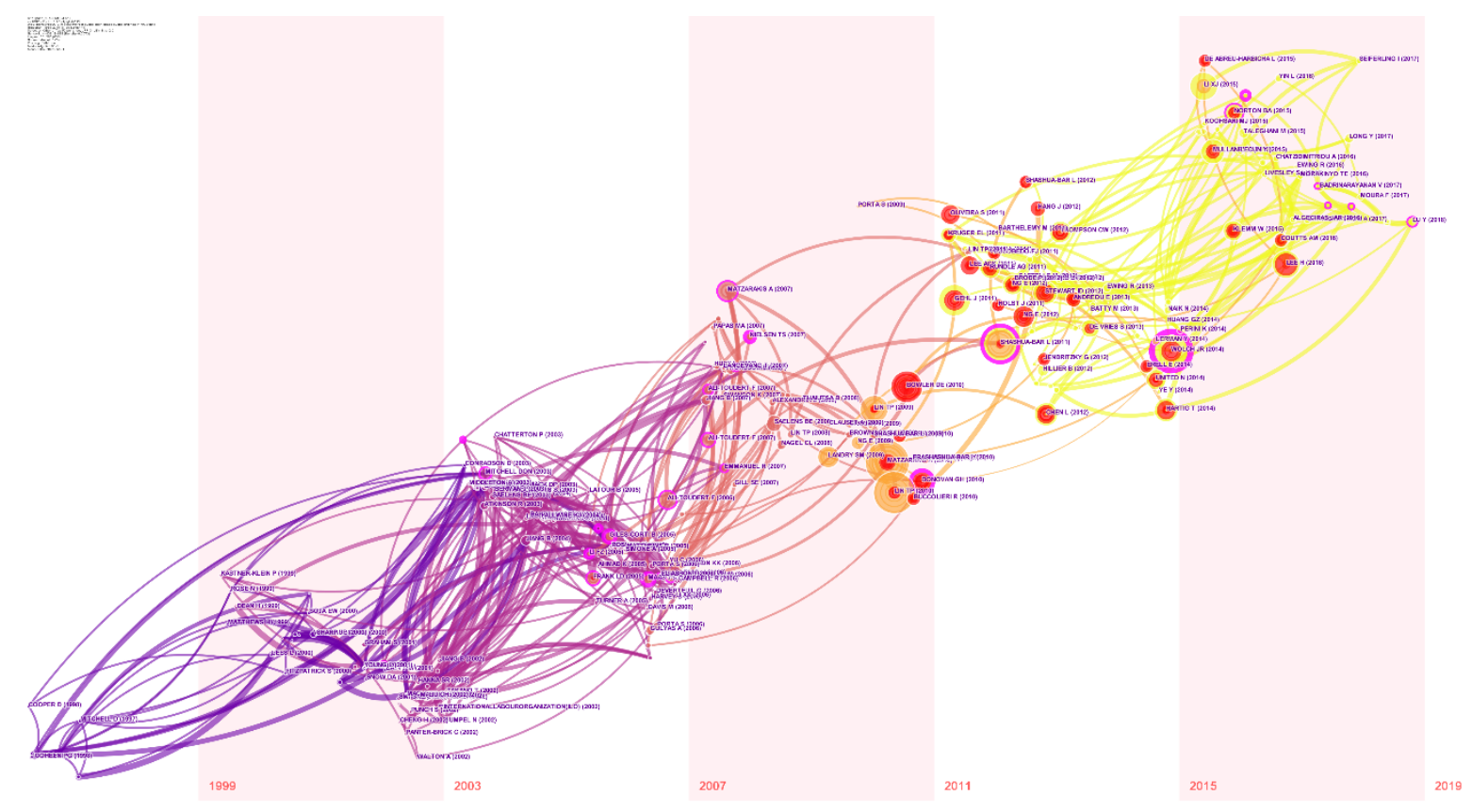

Figure 12. Research topic time zone view.

0 Clustering-The research theme of the cluster is destination. There are 33 research references in this cluster. In addition to the destination topic, these references also involve building, reflective roof, Barcelona, visual, energy, urban accidents, social environments and other related research topics. Based on the topic distribution and frequency of citations, the core literature of the topic clustering can be obtained. In the core literature, Diana E. Bowler and others comprehensively analyzed research data on the cooling effect of parks through Meta-Analysis. The temperature of the green park is about $1{ }^{\circ} \mathrm{C}$ lower, but the result still needs to be properly monitored in multiple urban green spaces (monitoring content should include comparing temperature data collected before and after the greening implementation plan with data collected from corresponding non-green spaces) to test this hypothesis [25]. Terry Hartig further discussed the definition of "nature," reviewed the four ways to gain health through exposure to nature in urbanized societies (air quality, outdoor activities, social interaction, and stress relief), and emphasized the intersection and diversity of research approaches [26]. Related directions for further research are discussed.

5 Clustering. Jan Gehl's Life Between Buildings: Using Public Space has indicated the landmark significance in the field of public space research centering on the images of street view. It classifies the outdoor space activities of the building into three categories, and analyzes the people in the place of stay in detail activities [27]. Sandra Oliveira found that the impact of small- and medium-sized green spaces in the city on the atmospheric environment in the surrounding space. Through the study and analysis of Lisbon, it emphasized that the cooling effect of green space on the surrounding environment should be enhanced in combination with the characteristics of urban space [28].

8 and 10 Clustering-There were climate models used to predict "heatwave days" in central Europe for next summer's weather, proving that trees are more effective than grasslands in terms of combating human heat stress [29]. Research by Riccardo Buccolieri and others showed that the correlation between air permeability in the urban canopy and building density provides a practical method for identifying the air permeability of urban spaces, and constructed a layout pattern of neighborhood building spaces in order to reduce pollution [30]. Wind speed, air temperature, and solar radiation affected human thermal perception. Edward $\mathrm{Ng}$ et al.'s research on the thermal comfort of Hong Kong believed that there are changes in the layout of buildings which are set up in urban open spaces and streets. The shading facility is beneficial to space users and emphasizes the effectiveness of plants in reducing local heat load [31]. Angeliki Chatzidmitriou carried out environmental measurements on 18 street 
canyons in the dense area of the center of Thessaliki, Greece, in summer and winter, respectively. The geometry of the street canyons is most beneficial for pedestrian thermal comfort experience [32]. In line with the concern of comfort experience, Ruey-Lung Hwang suggested that by conducting outdoor thermal environment experiments on urban streets in central Taiwan, as well as planting trees and installing awnings in street spaces, are recommended for improving the thermal environment of the original space [33].

Moreover, there are additional arguments such as human stress level from the surrounding environment and the concern about environmental justice. For example, Thompson tried to experiment with salivary cortisol as a biological way to measure changes in stress levels in humans. This approach is more objective and supports previous experimental research on the relationship between green space and stress relief [34]. Jennifer R. Wolch and others discussed the issues of environmental justice caused by the uneven distribution of green space in cities, and explained the duality of the problem. The increase in green space may raise the cost of housing, make the land aristocratic, and cause new, unfair events where managers and practitioners should pay attention and understand the concept of "just green enough" [35]. As such, they all provide various points of view to indicate the possible engagements for not only improving quality of street space but also residents' health in urban areas.

\subsection{Analysis of Street Space and Residents' Health Evolution Based on Iconic Literature}

This paper first uses CiteSpace to convert the literature from 1999 to 2019 by co-citation network, and then inputs the annual network information files into the Alluvial Generator one by one. After information screening and layout adjustment, we got 2012, as shown in Figure 13. The alluvial flow map of the landmark literature on street space and residents' health was taken from year to year up to 2019. In the picture, four iconic documents are highlighted. Among them, Cohen et al.'s is a document about trees that can effectively improve the heat of urban open spaces [36], and this document has a long shock streamline, which has received concentrated attention from 2012 to 2015. Edward Ng et al. conducted research on outdoor thermal comfort in Hong Kong. According to the analysis of the research results, Hong Kong's summer neutral physiological equivalent temperature (PET) is about $28^{\circ} \mathrm{C}$. This result helps to establish thermal comfort in hot and humid tropical and subtropical cities' wind performance standards [33]. At the same time, they believe that air humidity, wind speed, and solar radiation intensity are factors that determine the thermal sensation of outdoor people. The alluvial flow generated by the above two documents was introduced by Tzu-Ping Lin et al. The research focuses on the acceptable thermal comfort range of park users, the impact on park utilization, and the characteristics of thermal adaptation that will affect the difference in utilization of various methods in different spaces [37], and reveal the importance of shading facilities in parks in those hot climate areas.

From economic viewpoints, there are related factors affecting housing price such as space pattern and greenery of urban planning. Xiao's research analyzes the impact of urban spatial pattern and economic capacity on housing prices in China, of which public green space, private green space and paid green space are three types of green space influencing factors of spatial pattern [38]. For instance, Stephen Law used the topology of the street network in his study. The structure is connected on how to define and perceive local areas; and from the perspective of real estate economists, it will have an impact on house prices, which is an important aspect of house price prediction models [39]. Barthelemy Marc's opinion on the conditional probability distribution of the shape factor in a given area defines the constituent factors of urban fingerprints, which will be the basis for classifying cities based on street patterns [40]. Additionally, in Lu's study, it emphasizes the importance of walking behavior in Hong Kong city, and the decision of walking behavior and the length of time are related to the greenery which people visually perceive in the street space, and the validity and reliability of evaluation through Google Street View is proposed, too [41]. 


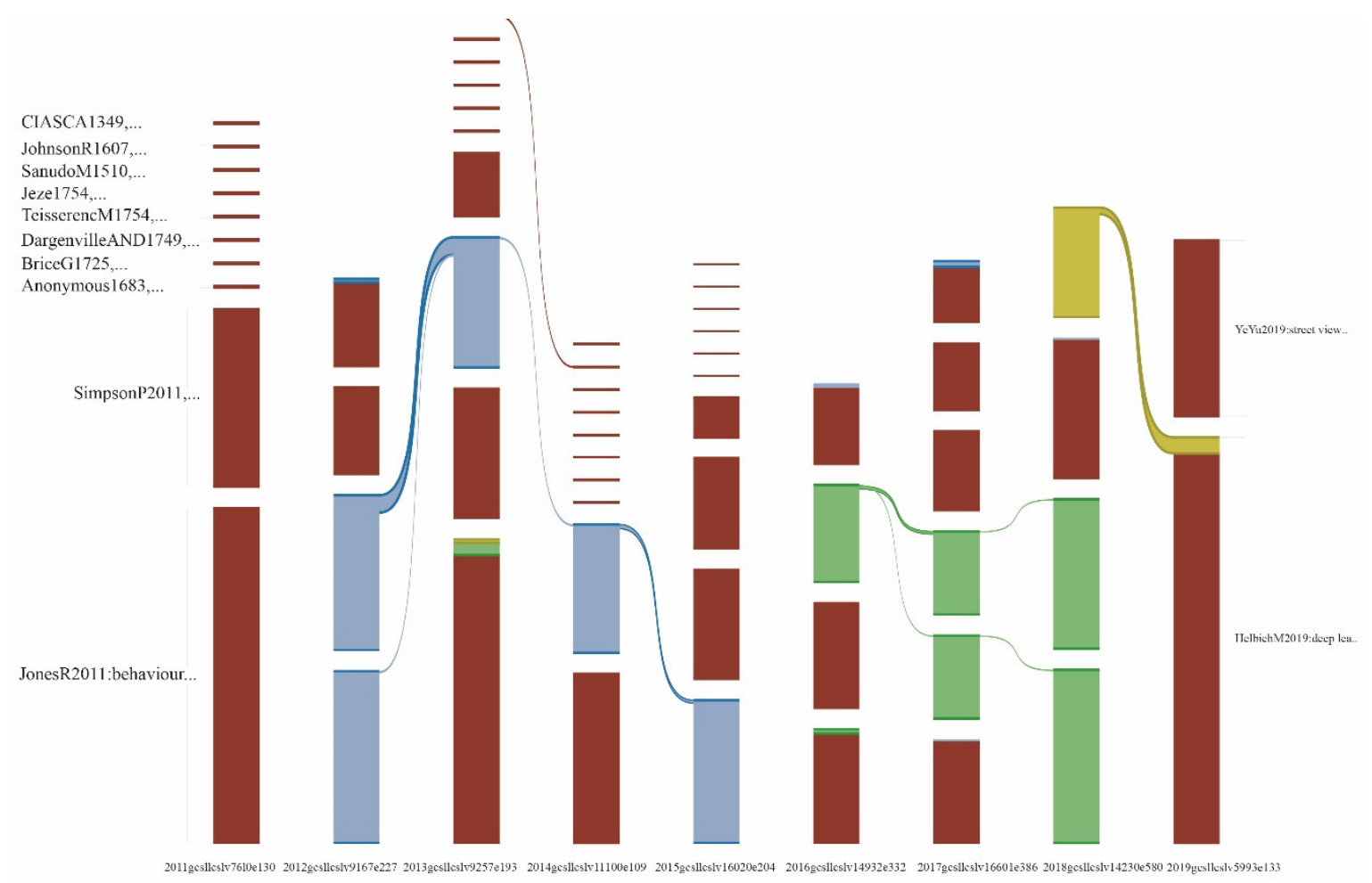

Figure 13. Alluvial flow map of the iconic literature.

The above analysis shows that "open space comfort," "the impact of different types of green space on living choices" and "street networks" are the main evolutionary contexts of street space and residents' health.

\section{Discussion}

This study uses the core of Web of Science to centrally integrate literature related to street space and residents' health research as a data source, fully integrate the advantages of bibliometric visualization software of CiteSpace and VOSviewer, and visualize the field of street space and residents' health research from a 1999 to 2019 analysis. First of all, based on the development trends of street space and residents' health research fields, subject categories, countries and research institutions, the preliminary analysis of street space and residents' health research development trends is conducted. Secondly, based on the knowledge-based analysis, knowledge topic recognition and knowledge topic evolution path analysis of the research field, this paper explores the research hotspots and frontiers in the past 20 years. By organizing the overall development path of this field, the paper intends to find out the regular patterns and future development trends to provide reference and basis for the development of the field. Through the classification of related researches in this field, the research scope and elements, methods and related contents are summarized and organized, and the following classifications are shown in Table 2.

Based on the co-citation from various literatures about street space and residents' health literature, it is found that the clustering characteristics of this research area are scattered to many research clusters, and there are no clear research characteristics formed. However, from the co-occurrence clustering and the emergence of this field, it is noticeable that Environmental Science and Ecology, Geography, Urban, Education and Educational Research, Multidisciplinary, Arts and Humanities are prevalent, revealing cross disciplinary research tendency in this area. 
Table 2. Positive correlation analysis of research fields.

\begin{tabular}{|c|c|c|c|c|}
\hline \multicolumn{3}{|c|}{ Research Categories and Elements } & Research Method & Relevant Research Contents \\
\hline \multirow{4}{*}{$\begin{array}{l}\text { Positive correlation } \\
\text { between urban street } \\
\text { space and residents' } \\
\text { health }\end{array}$} & $\begin{array}{c}\text { Natural } \\
\text { Environment }\end{array}$ & $\begin{array}{l}\text { temperature, plants } \\
\text { and geographical } \\
\text { location }\end{array}$ & $\begin{array}{l}\text { sensor measurement, } \\
\text { ENVI-met model, } \\
\text { literature meta analysis }\end{array}$ & $\begin{array}{l}\text { Psychological restoration and physical activity to explain the health } \\
\text { promoting value of green space [42,43]; Regional climate change [44]; Living } \\
\text { away from green spaces may increase the risk of obesity [45]; High-albedo } \\
\text { materials [46]; The sky view factor (SVF), significantly affects outdoor } \\
\text { thermal environments [47,48]; Google Street View (GSV), urban greenery } \\
\text { assessment tool [49,50];Three mechanisms through which greenery might } \\
\text { exert its positive effect on health: stress reduction, stimulating physical } \\
\text { activity and facilitating social cohesion [51-53]. }\end{array}$ \\
\hline & $\begin{array}{l}\text { Economic } \\
\text { Environment }\end{array}$ & $\begin{array}{l}\text { economic level and } \\
\text { house price of } \\
\text { different cities }\end{array}$ & $\begin{array}{l}\text { a topological network } \\
\text { model, space syntax re- } \\
\text { search, questionnaire } \\
\text { investigation }\end{array}$ & $\begin{array}{l}\text { Balancing the interests of all parties (local governments, different community } \\
\text { groups, real estate developers, environmental advocates) [35]; The concept of } \\
\text { Street-based Local Area (SLA), SLA associate with house price [39]; By } \\
\text { estimating network accessibility variables across a variety of spatial scales, } \\
\text { Evaluate the relationship between urban allocation and real estate price; } \\
\text { Urban Street centrality and densities of commercial and service activities [54]. }\end{array}$ \\
\hline & $\begin{array}{l}\text { Physical Space } \\
\text { Environment }\end{array}$ & $\begin{array}{l}\text { transportation, street } \\
\text { grid, built } \\
\text { environment }\end{array}$ & $\begin{array}{l}\text { computational fluid } \\
\text { dynamics (CFD), } \\
\text { standard ke3 turbulence } \\
\text { model, } \\
\text { micro-meteorological } \\
\text { measurement, } \\
\text { ENVI-met model, } \\
\text { space syntax }\end{array}$ & $\begin{array}{l}\text { The influence of thermal comfort of urban outdoor space environment on } \\
\text { pedestrians [55,56]; Geometric elements and physical properties are related } \\
\text { to microclimate and thermal comfort parameters as well as data from } \\
\text { different climatic regions [32]; Long-street models [57]; The urban air } \\
\text { permeability in the urban canopy is closely related to the building density } \\
\text { [58]; A small building arrangement and pollutant dispersion in street } \\
\text { canyons [59-61]; Environmental sensitivity and heat island intensity in } \\
\text { high-density cities [62,63]; The betweenness centrality (BC) of nodes in large } \\
\text { complex networks [64]; Planners and community police, the quality of life in } \\
\text { urban neighborhoods [65]; The large urban street networks form } \\
\text { small-world networks [66,67]; Cognitive space, metric space, spatial } \\
\text { topological [68]; Built environment space perception [69]. }\end{array}$ \\
\hline & $\begin{array}{c}\text { Social } \\
\text { Environment }\end{array}$ & $\begin{array}{c}\text { gender, age, } \\
\text { gentrification of land, } \\
\text { environmental } \\
\text { justice }\end{array}$ & $\begin{array}{l}\text { salivary cortisol data, } \\
\text { sampling survey }\end{array}$ & $\begin{array}{l}\text { Measurement of salivary cortisol was used as a basis for exploring the } \\
\text { relationship between happiness and green space [34]; The degree of urbanity } \\
\text { and level of income deprivation [70]; The association between greenery filled } \\
\text { public areas that are nearby a residence and easy to walk in and the } \\
\text { longevity of senior citizens in a densely populated, developed megacity } \\
\text { [71,72]; The obesity epidemic in minority children [73];Ethno-racially } \\
\text { differentiated [74-76]; The relationship between children's health and } \\
\text { community, green plants and sports activities [77]; The time of outdoor } \\
\text { activities are influenced by regional culture [78]. }\end{array}$ \\
\hline
\end{tabular}


From the perspective of countries and institutions, there are 67 major research countries involved in this research field. United States has become the main research country in this field with its absolute cooperative influence, followed by the United Kingdom and China. Among the 326 major research institutions involved, the most influential institution is UCL, followed by University of Melbourne and University of Hong Kong. In the knowledge base, Matzarakis [79], Lin [80], Shashua-bar [81] and other cited documents appear with a strong indication due to their co-citation relationship with other related researches. Academic influence and those highly cited literatures constitute the knowledge base in the research field on street space and residents' health. In terms of research topics, there are 12 clusters in the topic clustering map related to street space and residents' health reflecting the hot topics in the past 20 years. It appears that pedestrian-level thermal comfort also establishes the research hotspot and frontier of street space and residents' health.

This paper provides researchers with an overview on studies related to urban street space and residents' health. Of course, this is only a part of the studies available, and is not comprehensive. Overall, the research object of this study is mainly centered on the daily life of residents. The space environment is unfolded, but the urban space environment has its own ecosystem. The paper aims to transform the urban space in order to build up an appropriate environment with the awareness of human health in urban areas. In the process of achieving this regard, it is worthwhile for researchers to re-think the ecological balance for the entire environment of cities. On the other hand, there are issues which are valuable for in-depth discussion under the contemporary urban context, such as how should urban street space respond to the occurrence of public health incidents; or through urban planning and design, whether it is possible to avoid likely problems from happening.

In addition, from the aspects of research content, the future trends may turn from the focus on correlation exploration to the study of causality. The level of research methodology including sampling questionnaire surveys and cross-sectional surveys will follow the constant advancement of technical tools and software models such as GIS and ENVI-met that provide more reliable data for research development. Additionally, there are scholars that have begun their study via research methods in physics and biology. Most of them are related to the uncertainties, for example, the diversity of research objects and the unknowingness of causality. In future research, related contents may be more extensive, and it should be further specific to different research objects. With the attention to these details, choosing a suitable research method still needs the research front to work harder in developing multi-dimensional exploration and in-depth expansion. Undoubtedly, research hotspots are closely related to social formations, and they have shifted from macro theoretical research in the past to concrete empirical research by focusing on the urban street space in the era of "new urban science" covering more scientific and effective guidance through urban data obtained. To sum up, the positive and negative impacts of urban street space on residents' health have been proven in many ways. However, how to effectively use street space to better serve residents' health is a need for urban design researchers to collaborate with the public, for future studies.

Author Contributions: L.M. and K.-H.W. provided the research idea and the purpose of this study topic; L.M. and K.-H.W. designed the research; L.M. and Q.W. collected and analyzed the data; L.M. wrote the paper; finally, K.-H.W. supervised, corrected, and revised this paper; R.B. corrected article language and made some suggestions. All authors have read and agreed to the published version of the manuscript.

Funding: This research received no external funding.

Acknowledgments: The authors are extremely grateful for the Sustainability journal editorial team's valuable comments on improving the quality of this article.

Conflicts of Interest: The authors declare no conflict of interest.

\section{References}

1. U.S. Bureau of the Census. Historical Statistics of the United States 1789-1945; U.S. Govt: Washington, DC, USA, 1949; p. 25. 
2. Edwin Chadwick Biography (1800-1890). Available online: http://www.faqs.org/health/bios/66/EdwinChadwick.html (accessed on 12 December 2019).

3. Li, J. The way out for health predicament in urbanization. Hist. Res. Anhui 2015, 3, 115-122.

4. Burnstein, D.E. Next to Godliness: Confronting Dirt and Despair in Progressive Era New York City; University of Illinois Press: Chicago, IL, USA, 2006; p. 141.

5. Murnford, L. The City in History; Mariner Books: London, UK, 2009.

6. Li, Y. Theories of Urban Space Susceptible Cause Diseases; China Architecture \& Building Press: Beijing, China, 2016; p. 67.

7. WHO. Preamble to the Constitution of the World Health Organization; World Health Organization: New York, NY, USA, 1946; p. 1.

8. Public-Space. Available online: https://new.unhabitat.org/topic/public-space (accessed on 6 November 2019).

9. Jacobs, J. The Death and Life of Great American Cities; Modern Library: New York, NY, USA, 1993; p. 56.

10. Goffman, E. Behavior in Public Places: Notes on the Social Organization of Gatherings; Free Press: New York, NY, USA, 1963; pp. 78-90.

11. Whyte, W.H. The Social Life of Small Urban Spaces; Ye, Q., Ni, X., Eds.; Shanghai Translation Publishing House: Shanghai, China, 2016; pp. 116-120.

12. Ungers, O.M. Morphologies: City Metaphors; Walther Koning. Verlag der Buchh and Lung König: Cologne, Germany, 2011; pp. 35-57.

13. Barton, H.; Grant, M.; Guise, R. Shaping Neighborhoods: a guide for Health, Sustainability and Vitality? Spon Press: London, UK, 2003; pp. 66-78.

14. New York City. Active Design Guidelines: Promoting Physical Activity and Health in Design; NYC: New York, NY, USA, 2011; pp. 13-18.

15. Jamison, D.T.; Summers, L.H.; Alleyne, G. Global health 2035: A world converging within a generation. Lancet 2013, 382, 1898-1955. [CrossRef]

16. Xu, L.Q.; Meng, R.X.; Huang, S.Q.; Chen, Z. Healing-oriented street design: exploration based on VR experiment. Urban Plan. Int. 2019, 1, 38-45. [CrossRef]

17. Non-Communicable Diseases. Available online: https://www.who.int/zh/news-room/fact-sheets/detail/ noncommunotable-diseases (accessed on 6 November 2019).

18. Chen, Y.; Chen, C.M.; Liu, Z.Y. Methodological function of CiteSpace knowledge map. Sci. Res. 2015, 33, $242-253$.

19. Li, J.; Chen, C.M. CiteSpace: Scientific Text Mining and Visualization; Capital University of Economics and Business Press: Beijing, China, 2016; pp. 78-89.

20. Waltman, L.; Eck, N.J.V.; Noyons, E.C.M. A unified approach to mapping and clustering of bibliometric networks. J. Informetr. 2010, 4, 629-635. [CrossRef]

21. Callon, M.; Courtial, J.P.; Laville, F. Co- word analysis as a tool for describing the network of interactions between basic and technological research. The case of polymer chemistry. Scientometrics 1991, 22, 155-205. [CrossRef]

22. Law, J.; Whittaker, J. Mapping acidification research: A test of the co-word method. Scientometrics 1992, 3, 417-461. [CrossRef]

23. Kleinberg, J. Bursty and hierarchical structure in streams. In Proceedings of the 8th ACM SIGKDD International Conference on Knowledge Discovery and Data Mining, Edmonton, AB, Canada, 23-26 July 2002; pp. 91-101.

24. Chen, C.M.; Chen, Y.; Hou, J. CiteSpace II: Identification and visualization of new trends and new dynamics in scientific literature. J. China Soc. Inf. Sci. 2009, 28, 401-421.

25. Bowler, D.E.; Buyung-Ali, L.; Knight, T.M.; Pullin, A.S. Urban greening to cool towns and cities: A systematic review of the empirical evidence. Landsc. Urban Plan. 2010, 97, 147-155. [CrossRef]

26. Hartig, T.; Mitchell, R.; Vries, S.D.; Frumkin, H. Nature and health. Public Health 2014, 35, 207-228. [CrossRef]

27. Gehl, J. Life Between Buildings: Using Public Space; Island Press: Washington, UK, 2011; pp. 56-66.

28. Oliveira, S.; Andrade, H.; Vaz, T. The cooling effect of green spaces as a contribution to the mitigation of urban heat: A case study in Lisbon. Build. Environ. 2011, 46, 2186-2194. [CrossRef]

29. Hyunjung, L.; Helmut, M.; Liang, C. Contribution of trees and grasslands to the mitigation of human heat stress in a residential district of Freiburg, Southwest Germany. Landsc. Urban Plan. 2016, 148, 37-50.

30. Buccilieri, R.; Sandberg, M.; Sabatino, S.D. City breathability and its link to pollutant concentration distribution with in urban-like geometries. Atmos. Environ. 2010, 44, 1894-1903. [CrossRef] 
31. Edward, N.; Vicky, C. Urban human thermal comfort in hot and humid Hong Kong. Energy Build. 2012, 55, 51-65.

32. Angeliki, C.; Simos, Y. Street canyon design and improvement potential for urban open spaces; the influence of canyon aspect ratio and orientation on microclimate and outdoor comfort. Sustain. Cities Soc. 2017, 33, 85-101.

33. Hwang, R.L.; Lin, T.P.; Matzarakis, A. Seasonal effects of urban street shading on long-term outdoor thermal comfort. Build. Environ. 2011, 46, 863-870. [CrossRef]

34. Thompson, C.W.; Roe, J.; Aspinall, P.; Mitchell, R.; Clow, A.; Miller, D. More green space is linked to less stress in deprived communities: Evidence from salivary cortisol patterns. Landsc. Urban Plan. 2012, 105, 221-229. [CrossRef]

35. Wolch, J.R.; Byrne, J.A.; Newell, J.P. Urban green space, public health, and environmental justice: The challenge of making cities 'just green enough'. Landsc. Urban Plan. 2014, 125, 234-244. [CrossRef]

36. Cohen, P.; Potchter, O.; Matzarakis, A. Daily and seasonal climatic conditions of green urban open spaces in the Mediterranean climate and their impact on human comfort. Build. Environ. 2012, 51, 285-295. [CrossRef]

37. Lin, T.P.; Tsai, K.T.; Liao, C.C.; Huang, Y.C. Effects of thermal comfort and adaptation on park attendance regarding different shading levels and activity types. Build. Environ. 2013, 59, 599-611. [CrossRef]

38. Xiao, Y.; Orford, S.; Webster, C.J. Urban configuration, accessibility, and property prices: A case study of Cardiff. Environ. Plan. B Plan. Des. 2015, 42,1-12. [CrossRef]

39. Law, S. Defining Street-based Local Area and measuring its effect on house price using a hedonic price approach: The case study of Metropolitan London. Cities 2017, 60, 166-179. [CrossRef]

40. Barthelemy, M. From paths to blocks: New measures for street patterns. Environ. Plan. B Plan. Des. 2017, 44, 256-271. [CrossRef]

41. Lu, Y.; Sarkar, C.; Xiao, Y. The effect of street-level greenery on walking behavior: Evidence from Hong Kong. Soc. Sci. Med. 2018, 208, 41-49. [CrossRef]

42. Hartig, T. Green space, psychological restoration, and health inequality. Lancet 2008, 372, $1614-1615$. [CrossRef]

43. Hartig, T. Three steps to understanding restorative environments as health resources. In Open Space: People Space; Thompson, C., Travlou, P., Eds.; Taylor and Francis: Abingdon, UK, 2007; pp. 163-179.

44. Patz, J.A.; Campbell-Lendrum, D.; Holloway, T.; Foley, J.A. Impact of regional climate change on human health. Nature 2005, 438, 310-317. [CrossRef]

45. Nielsen, T.S.; Hansen, K.B. Do green areas affect health? Results from a Danish survey on the use of green areas and health indicators. Health Place 2007, 13, 839-850. [CrossRef]

46. Erell, E.; Pearlmutter, D.; Boneh, D.; Bar Kutiel, P. Effect of high-albedo materials on pedestrian heat stress in urban street canyons. Urban Clim. 2014, 10, 367-386. [CrossRef]

47. Holst, J.; Mayer, H. Impacts of street design parameters on human- biometeorological variables. Meteorol. Z. 2011, 20, 541-552. [CrossRef]

48. Taleghani, M.; Kleerekoper, L.; Tenpierik, M.; Dobbelsteen, V.D.A. Out- door thermal comfort within five different urban forms in the Netherlands. Build. Environ. 2015, 83, 65-78. [CrossRef]

49. Li, X.J.; Zhang, C.R.; Li, W.D.; Ricard, R.; Meng, Q.Y.; Zhang, W.X. Assessing street- level urban greenery using Google Street View and a modified green view index. Urban For. Urban Green. 2015, 14, 675-685. [CrossRef]

50. Liang, J.M.; Gong, J.H.; Sun, J.; Zhou, J.P.; Li, W.H.; Li, Y.; Shen, S. Automatic sky view factor estimation from street view photographs-A big data approach. Remote Sens. 2017, 9, 411. [CrossRef]

51. Gascon, M.; Triguero-Mas, M.; Martinez, D.; Dadvand, P.; Forns, J.; Plasencia, A.; Nieuwenhuijsen, M.J. Mental health benefits of long-term exposure to residential green and blue spaces: A systematic review. Int. J. Environ. Res. Public Health 2015, 12, 4354-4379. [CrossRef] [PubMed]

52. Markevych, I.; Schoierer, J.; Hartig, T.; Chudnovsky, A.; Hystad, P.; Dzhambov, A.M.; de Vires, S.; Triguero-Mas, M.; Brauer, M.; Nieuwenhuijsen, M.J.; et al. Exploring pathways linking greenspace to health: Theoretical and methodological guidance. Environ. Res. 2017, 158, 301-317. [CrossRef] [PubMed]

53. Sarkar, C.; Webster, C.; Pryor, M.; Tang, D.; Melbourne, S.; Zhang, X.H.; Liu, J.Z. Exploring associations between urban green, street design and walking: Results from the Greater London boroughs. Landsc. Urban Plann. 2015, 143, 112-125. [CrossRef]

54. Porta, S.; Strano, E.; Iacoviello, V.; Messora, R. Street centrality and densities of retail and services in Bologna, Italy. Environ. Plan. B Plan. Des. 2009, 36, 450-465. [CrossRef] 
55. Cheng, V.; Ng, E. Thermal comfort in urban open spaces for Hong Kong. Archit. Sci. Rev. 2006, 49, $236-242$. [CrossRef]

56. Thorsson, S.; Honjo, T.; Lindberg, F.; Eliasson, I.; Lim, E.M. Thermal comfort and outdoor activity in Japanese urban public places. Environ. Behav. 2007, 39, 660-684. [CrossRef]

57. Hang, J.; Sandberg, M.; Li, Y.G. Flow mechanisms and flow-capacity in idealized long-street models. Build. Environ. 2010, 45, 1042-1053. [CrossRef]

58. Buccolieri, R.; Gromke, C.; Di Sabatino, S.; Ruck, B. Aerodynamics effects of trees on pollutant concentration in street canyons. Sci. Total Environ. 2009, 407, 5247-5256. [CrossRef]

59. Di Sabatino, S.; Buccolieri, R.; Pulvirenti, B.; Britter, R.E. Flow and pollutant dispersion in street canyons using FLUENT and ADMS-Urban. Environ. Modeling Assess. 2008, 13, 369-381. [CrossRef]

60. Pearlmutter, D.; Berliner, P.; Shaviv, E. Integrated modeling of pedestrian energy exchange and thermal comfort in urban street canyons. Build. Environ. 2007, 42, 2396-2409. [CrossRef]

61. Ali-Toudert, F.; Mayer, H. Numerical study on the effects of aspect ratio and orientation of an urban street canyon on outdoor thermal comfort in hot and dry climate. Build. Environ. 2006, 41, 94-108. [CrossRef]

62. Chao, Y.; Edward, N. Practical application of CFD on environmentally sensitive architectural design at high density cities: A case study in Hong Kong. Urban Clim. 2014, 8, 57-77.

63. Giridharan, R.; Lau, S.S.Y.; Ganesan, S.; Givoni, B. Urban design factors influencing heat island intensity in high-rise high-density environments of Hong Kong. Build. Environ. 2007, 42, 69-84. [CrossRef]

64. Barthelemy, M. Betweenness centrality in large complex networks. Eur. Phys. J. B 2004, 38, 163-168. [CrossRef]

65. Michael, B. Cities and Complexity; The MIT Press: Cambridge, MA, USA, 2005; pp. 67-86.

66. Jiang, B.; Claramunt, C. Topological analysis of urban street networks. Environ. Plan. B 2004, 31, 151-162. [CrossRef]

67. Sergio, P.; Paolo, C.; Vito, L. The network analysis of urban streets: A primal approach. Environ. Plan. 2006, B33, 705-725.

68. Penn, A. Space syntax and spatial cognition or why the axial line? Environ. Behav. 2003, 35, 30-65. [CrossRef]

69. Koohsari, M.J.; Karakiewicz, J.A.; Kaczynski, A.T. Public open space and walking: The role of proximity, perceptual qualities of the surrounding built environment, and street configuration. Environ. Behav. 2013, 45, 706-736. [CrossRef]

70. Mitchell, R.; Popham, F. Greenspace, urbanity and health: Relationships in England. J. Epidemiol. Community Health 2007, 61, 681-683. [CrossRef] [PubMed]

71. Sullivan, W.C.; Kuo, F.E.; Depooter, S.F. The fruit of urban nature vital neighborhood spaces. Environ. Behav. 2004, 36, 678-700. [CrossRef]

72. Takano, T.; Nakamura, K.; Watanabe, M. Urban residential environments and senior citizens' longevity in megacity areas: The importance of walkable green spaces. J. Epidemiol. Community Health 2002, 56, 913-918. [CrossRef]

73. Bush, C.L.; Pittman, S.; McKay, S.; Ortiz, T.; Wong, W.W.; Klish, W.J. Park- based obesity intervention program for Inner-city Minority Children. J. Pediatrics 2007, 151, 513-517. [CrossRef] [PubMed]

74. Byrne, J. When green is White: The cultural politics of race, nature and social exclusion in a Los Angeles urban national park. Geoforum 2012, 43, 595-611. [CrossRef]

75. Byrne, J.; Wolch, J. Nature, race, and parks: Past research and future directions for geographic research. Prog. Hum. Geogr. 2009, 33, 743-765. [CrossRef]

76. Dai, D. Racial/ethnic and socioeconomic disparities in urban green space accessibility: Where to intervene? Landsc. Urban Plan. 2011, 102, 234-244. [CrossRef]

77. Almanza, E.; Jerrett, M.; Dunton, G.; Seto, E.; Pentz, M.A. A study of community design, greenness, and physical activity in children using satellite, GPS and accelerometer data. Health Place 2012, 18, 46-54. [CrossRef]

78. De Vries, S.; Van Dillen, S.M.E.; Groenewegen, P.P.; Spreeuwenberg, P. Streetscape greenery and health: Stress, social cohesion and physical activity as mediators. Soc. Sci. Med. 2013, 94, 26-33. [CrossRef]

79. Matzarakis, A.; Rutz, F.; Mayer, H. Modelling radiation fluxes in simple and complex environments: Basics of the RayMan model. Int. J. Biometeorol. 2010, 54, 131-139. [CrossRef] 
80. Lin, T.P.; Matzarakis, A.; Hwang, R.L. Shading effect on long-term outdoor thermal comfort. Build. Environ. 2010, 45, 213-221. [CrossRef]

81. Shashua-Bar, L.; Pearlmutter, D.; Erell, E. The influence of trees and grass on outdoor thermal comfort in a hot-arid environment. Int. J. Climatol. 2011, 31, 1498-1506. [CrossRef] 